\title{
Molecular identification of Insect species and their applications
}

\author{
Naser Alkenani and Habeeb M. Al-Solami \\ Department of Biological Sciences, Faculty of Science, P.O. Box 80203, King Abdulaziz University, Jeddah, 21589, Saudi Arabia
}

Correspondence Author: Naser Alkenani, Department of Biological Sciences, Faculty of Science, P.0. Box 80203, King Abdulaziz University, Jeddah, 21589, Saudi Arabia

Email: nkenani@gmail.com

Received date: 20 June 2019, Accepted date: 12 August 2019, Online date: 25 August 2019

Copyright: (c) 2019 Naser Alkenani and Habeeb M. Al-Solami, This is an open-access article distributed under the terms of the Creative Commons Attribution License, which permits unrestricted use, distribution, and reproduction in any medium, provided the original auth or and source are credited.

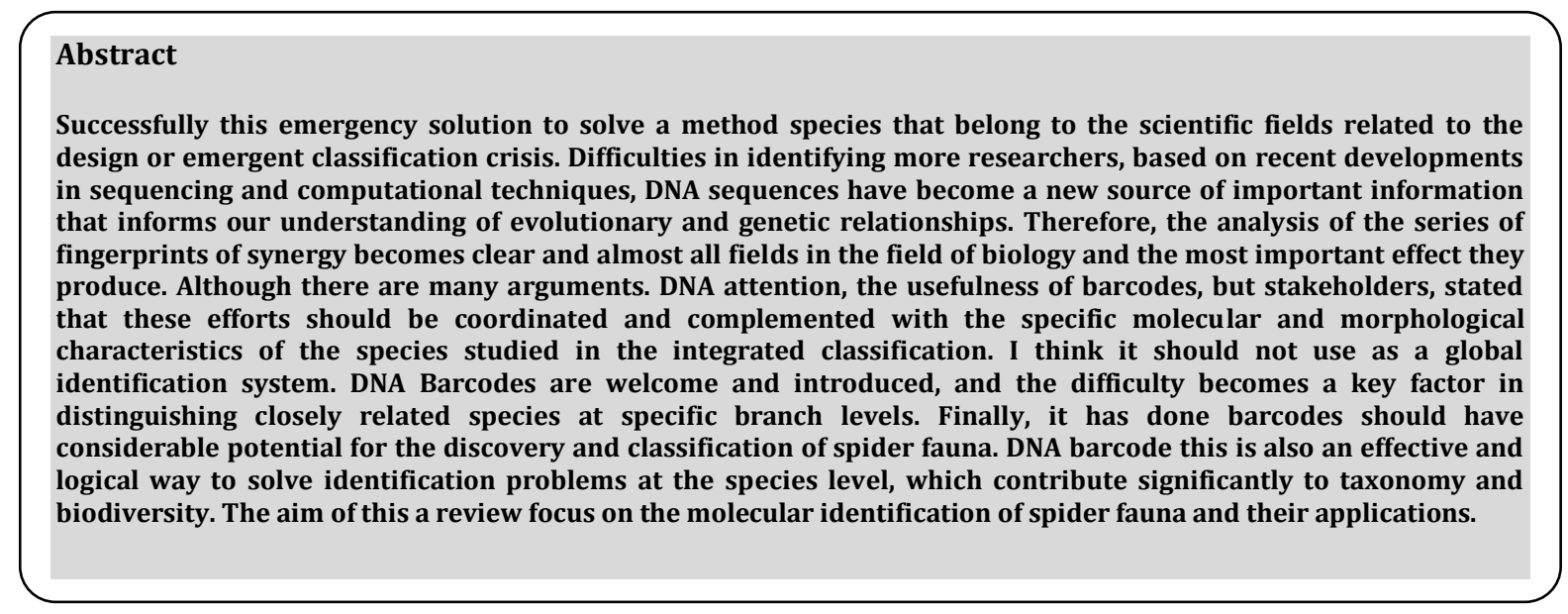

Keywords: Molecular, identification, DNA, barcodes, Insect species identification applications

\section{INTRODUCTION}

Several field surveys are an essential part of the various traditional and modern desert ecosystems of Western Saudis. Online agriculture royal spider in the vibrant and accessible region Araneae group of animals clarify the presence. The wire of time another valuable predator these spiders like dividing the breeders because biocides play an essential role in different types of pests and small arthropods. Besides, these spiders are talented hunters in a variety of terrestrial environments in many places and show great potential to reveal subtle changes in environmental variables, summer bell and so on right away, 2005. New animal species in the world and review current passage the number determination of the excellent presentation of the scientific community. Real Your options will not be exhausted. When many renowned scientists embark on this global test, they have great beliefs and impulses from new technologies to identify these challenges and examine them from an appropriate scientific point of view. These efforts begin Some other scientists thanks to advanced reinforcements. It is a new Idea in this approach that reported using very short genetic sequences of the standard part of the genome; Supermarket browser uses the universal product code to distinguish the product as black lines. The main idea is but, two, the reason for the unprofessional assumption of the article in the eye or seemingly very similar view is that the barcode is distinguished by two conditions [1].

Participating in research to document and test the real wealth of the Web in Western Saudi Arabia is becoming the priority of this stage. Therefore, we will use the latest technology DNA barcode tools to identify the main popular types and master all these different desert areas, Sycuan's 2006. Currently, the classification and classification of species systematically. For all the ecology 
online biota any ecological or environmental. Scratch evil search all It is vital besides, the rating of complex dynamic science (is simple rather than correspond to reality, genomics. Taxonomists regularly filter many observations from an extensive knowledge base to identify a set of examples or taxa that constitute a new taxonomic group. In addition, the great efforts and extensive research carried out by leading scientists have further strengthened the engineering base, and tested DNA barcode determination of real spiders, activity, and power, they believe that this program is valid for all eukaryotes, and they hope that they can be approved and display a bar code for life if they are implemented. This will lead to automated systems that identify and discover many types. Besides, recent investigations such as a mitochondrial cytochrome c oxidase encoding wild spider that stains a gene, a local short highlight. Therefore, the early detection of DNA barcodes does GUM it Building very useful for children. What a fix He was adulthood requires gender matching of morphological identification and morphological stages of life and is used to iso late types of secrets unknown or closely related [2]. In western Saudi Arabia, more work has been done to document this. In many desert ecosystems. Some insect as spider real Spider eye) Rich fauna Rio Seco agriculture - ecosystem and palm garden inventory and discovery on the site called trucks misplaced wildlife Presence These spiders control many parasites in different cultures. The administration plays a significant role [3-4]. The aim of this review focus on the molecular identification of spider fauna and their applications.

\section{MOLECULAR IDENTIFICATION}

The deadliest disease that kills millions of people every year. Vector diseases caused by insects. Average result 50 Dengue is the most important [5]. Dengue (DFA) Tropical and subtropical regions a mosquito has infected it. The fastest increase is a major public health problem. In the world, it causes more diseases and deaths than other arboviruses in humans [6-7]. Dengue sangria heat around 500,000 blankets Annual length of stay need of these are children It is widely accepted in Southeast Asia, but the real event is not right. Documented [8-9]. Dengue Virus a first in Jeddah, isolated Saudi Arabia, later 2006 an outbreak has occurred, and sporadic cases have been reported in Jeddah and Mecca in western Saudi Arabia. Egypt A local mosquito is responsible for creating a dengue virus. Three serotypes of hazards were detected: DENV. - 1, DENV - 2 and DENV - 3 [10,11]. The four serotypes of DENV are usually cyclized with genotypic mutations that occur between isolates of serotypes [12, 13]. Denver antidetection, including infection, clinical inspection dengue Virus Antibodies and / Viral antigen, virus isolated or between Denver to molecular detection [14] use ELISA anti- Denver IgM and IgG antibody if present, the most useful method of serological diagnosis in the acute case, IgM may be an antibody in disease attack later 3 to 5 The day appears and continues. 3 for 5 months Anti-dengue IgG Antibody levels are relatively low, in secondary infections, IgM antibodies [15, 16]. Serological inspection It is easy and easy to use in the face of an epidemic, many cases are necessary, but it is difficult to distinguish the characteristics of the serotype of dengue fever. Traditional methods of detection and serotyping. the infected DENVER if serological identification with cell culture [14]. But they work intensively about a week, requires a weak sensitivity and laboratory. Reverse transcription (RT). The diagnosis of a molecular basis is replaced by the PCR. RTA - PCR is one of the most important steps in the molecular diagnosis with DENV. There are several laboratories. Output to Several DENVER identified RT-PCR, provision, conventional use PCR and real-time RT-PCR, [17-19].

DFA Without treatment or particular vaccine [20-21]. Therefore, the early detection of viral infections is essential to avoid possible attacks. Recently in the city-regional epidemic of DENVER, it was in the western part of Saudi Arabia. Medina adjacent to Jeddah and Makkah, the population is dense, not previously reported Al-Medina DENVER activity. Intersection molecular and seropositive tests were performed. Received to what extent the community of Medina exposed to dengue fever.

\section{DNA barcodes a type of identification}

Mosquito eyes insects if $\mathrm{nm}$ anthocorid it is a fly and the mosquitoes of the family. In the world, we have 3500 different microorganism Species [22] in Swedish located around 50 species aegypti (och) sticticus of, for example, flood mosquito Largescale incubation and gray aegypti (a gray) Annoy people and animals each year. In some areas, for instance, Nedra the problem is very serious, authorities biocidal computing chooses a spray [23]. More importantly, the appearance of these mosquitoes. The risk of zoonotic disease. It increases because it is associated with many mosquito vectors, such as arboviruses and parasites. Nedra mosquito the mechanism behind the emergency It is not true. However, rainwater production or area the accumulation of large amounts of water can cause problems to plants. The Swedish government has begun to develop a more sustainable problemsolving strategy, especially in the area of infection control [24].

\section{Identification of the variety of DNA barcodes morality}

The methods of identification, labelling, and classification of organisms are based mainly on morphological characteristics. Linus pugnacity for 18 years. The classification system developed during the century is still primarily used. Nowadays, taxonomists are studying new methods of population physiology, behavior and biology. DNA the discovery by accepting its role in inheritance, genetic diversity plays an essential role in the distinction of biodiversity. The morphological descriptions of the species are limited because phenotypic plasticity is not considered, for example, potential taxonomic groups or specific stages of life [25-26]. Identification based on DNA fills these gaps and, what is more important, adds new biodiversity to obvious things. Molecular-based methods are commonly used for taxonomic studies of species in which viruses, bacteria, and protozoa are identified [27] In a more general approach, whole-genome alignment and other sequence-based methods are used to describe diversity. Another method, microsatellites, AFLP Biomarkers such as to analyze or PNS [28]. However, due to the great diversity of biodiversity, this method is not suitable for arthropods. It will be expensive and slow. A more appropriate way for identifying substances is the analysis of small segments of genes called DNA barcodes [25]. Since the rate of molecular evolution depends on the part of the genome studied, the most appropriate genetic segment for this type of analysis is discussed. However, in animals, 
the mitochondrial genome. and no intron in small recombination's, it seems that the bar code is more appropriate than the nuclear genome. The maternal inheritance of mitochondrial genes can also be used in bar codes. (12S, 16S) Mitochondrial DNA gene ribosomes about the barcode performed before However, placements, and deletions (deletions) are characteristic in these genes, complicating the sequence models [29]. Nuclear and ribosomal in plants and fungi. DNA ITS2 the barcode of the field seems to go a better option [30]. Coding of animal-marrow proteins.

Genes 13 the type, the use of which genes are unclear. Cytochrome b oxidase in the bar code gene studies, other considerations have 1 gene only CO Yes [31]. Many conserved sequences and, therefore, the universal primers developed for this gene are very robust [32]. Compared with mitochondrial genes, phylogenetically, the CO signal has a higher yield than seen. Base substitution of formed nucleotides is more common; It is quite high for the proportion of genes used for evolution [33]. CO despite small twospecies mutations in genes\% but it is enough to isolate phylogenetic species and differentiate related species. This is because the difference between the species more than five times is the average [34]. The coding of the DNA barcodes is now done routinely using the traditional PCR and Sanger sequences. Ten years an NGS type has been developed. New classification technology Since this technology combines DNA capture, PCR and sequence reactions; it may be suitable for DNA barcodes. Other sports to support DNA barcodes to facilitate access to table data, barcode, public research and life bar code (CBOL International Consortium was created. This DNA is to be encoded to bar 50 It has become the global standard for biometrics in 200 countries and organizations work together to encourage it barcode from one member of the mosquito alliance barcode initiative target all species of mosquitoes 80 only). At least 5 to sample code DNA - pubs. Solid portal support. Users, data processing resources and structural data storage to provide analysis tools. The barcode data is related to the classification, geographical location, and image. The objective is to create a reference database that contains records of tables that confirm all types of all taxa [35].

\section{Applications of DNA barcode}

This labor goal this DNA Barcodes are an effective and reasonable way to solve the problem of identification at the species level and contribute significantly to taxonomy and biodiversity goal. Western Saudi Arabia rich can happen problem Classification of different species of domestic spiders. Nature and desert agriculture, it does not harm the ecosystem. Continue to provide more information about biodiversity., For this reason, the research proposal. It satisfies the need for an essential group of invertebrate hunters and includes the following objectives. Critical data to produce large populations of spider animals. Nature and agricultural ecology system. The real main rescue of spiders in Japan. Seasonal changes and population dynamics. Morphology, molecular and DNA code - bars in use Try to identify these representatives of immature and adult spiders. Create a complete structure. DNA Article Library Sequence desert spider code. In this age and age, understand and Information about the growth and prosperity of modern science of biological diversity for produce interest.

Real seasonal fluctuations of animals and spiders in western Saudi Arabia. Recycling of the main components of biodiversity in desert ecosystems, including arthropods and spiders. Training in modern technology for Saudi graduates. DNA coding sequence of the structure desert spider. Full DNA Barcode library manufacturing control central desert spider. In the whole world Net modern research and extraordinary scientists Habitats of the world 40,000 of them in real spider Araneae, specify. In addition to defined marine and freshwater environments, this figure may represent only a small part of the overall diversity [25]. In addition to sexual dimorphism, the information of the identified species modern systems of social mating. study for an important starting point from studies who must supply. Most systems identification processes are based on traditional external morphological characteristics and labor has tried to improve this method. They asked many questions and a lot of originality. Use. I brought a threat. For this reason, morphological characteristics are inherently problematic and can be considered as taxonomic obstacles or obstacles [36, 37].

Also, the morphological identification of most species levels is mainly based on adulthood, which requires a detailed analysis of genital morphology, but there is no possibility for babies and other stages of life, and It is almost impossible to reveal your property. Besides, gender dimorphism leads to serious synonym problems. This is especially the reason for all the spiders. Original description half Based on a sample one. In addition, some potential species need to be restored. To make these problems more complicated or confusing. There is nothing to do [38]. Also, genomic polymorphisms have recently been found in some species of spider species, which increases the uncertainty and terminology of classification decisions. Example of barcode element, that is. Laboratory analysis Counted and included [39] — database and data analysis of four components.

DNA The barcode is considered. Genetic diversity between species, because the abbreviated sequences can differentiate between individual species in types to overtake. Many researchers have identified large animals, including birds [39]. Fish neighborhood Lepidoptera el Hajibabae Test the rationality and effectiveness of this intelligent approach. The most applied research is the plant. Algae mushroom Summer belt) For other creatures to establish DNA Barcode system including. Single-cell bacteria [40]. Up to here Based on the DNA, the methods are widely discussed since many incompatible natural incompatibilitie s support each other, including classification (Good or bad) Some special community. This argument refers to careless fears that threaten traditional ways. later [41].

The main objective of the applications of DNA barcode is the modernization and activation of modern taxonomic tools. In this context, [42]. By introducing the inconsistencies and specific limitations of traditional morphology, users are asked to find molecular diversity as a rational tool to identify and define different organisms, in addition, identify undetected biodiversity to heat components of unexplored efforts. The possible researchers and experts decrease in number because it becomes complicated, it is clarifying the attention closely DNA Barcodes can be further clarified in the classification of restriction errors based on the single form. Advanced experience List these gaps, including absenteeism. It will also be limited to a specific order, family or classification, if applicable. In addition, the genetic plasticity of the phenotypes sometimes leads to misidentification, and the addressing of the letters can define any type. The absence of classification keys in the maturation stage increases the presence of possible types of fraternities that can sometimes be ignored during the identification process. 
Citation: Naser Alkenani and Habeeb M. Al-Solami, 2019. Molecular identification of Insect species and their applications. Advances in Environmental Biology 13(8): 17-24. DOI:10.22587/aeb.2019.13.8.2

\section{DNA sequences}

DNA in the reason for Because the sequences are species-specific, the taxonomists of biodiversity believe that the validity of genetic barcodes is not surprising. This has great potential to solve the fundamental classification problems that are currently being implemented. The well informed, scientifically proven, by 4 nitrogenous bases (A, T, C, G) possible mutations in nucleotides. Each site 4 there is n (including "K") detailed review corresponding nucleotide number. Therefore, the possible code for any sequence identifies each taxonomic group. One hundred million look only 15 Position of the nucleotide species 415 seed discover something recognizable surely hurts Yes. General products determination quickly and adjust and make profitable. Professional taxonomists group in need dating from another significant benefit of this scientific diagnostic approach is its ability to identify all stages of infant and immature development and to reduce efforts to differentiate morphologically identical species. There are more classification Scientific thinking DNA Bar codes are a diagnostic tool widely used in science and often describe women who are often indistinguishable and often indistinguishable from indistinguishable spiders. This provides advice for men and women at different times and places. Species hid with diversity. And continuous detection of radiation. DNA Behind the barcode the basic principle is to support the traditional taxonomy and ongoing research, by providing general information if the morphological characteristics are not well expressed. The most attractive candidates for implementing barcode data are species that are closely related to species, with species with numbers of separation, and possible problems with sibling species or species radiation are rare in spiders [25]. Up to now, DNA the accumulation of bar codes offers a great potential for the conservation of biodiversity, the estimation of biodiversity and the monitoring of the management of invasive alien species or important medical species. Wealth created. DNA code - Bars Pair of spiders, the most effective and aggressive potential. Yes, many examples are Complete and detailed in the inventory of species as well as examples of all habitats in different communities. The research work in a truck Each population redistributed these collected samples. These efforts are more important to complement these central databases. DNA Density of possible barcode and complete search of species in [37]. Think in the same way [43] DNA The identification of the barcode method is not a real alternative to taxonomic analysis, that is, if an unknown species does not comply with the current bar code record, the Barcode sequence is unknown and cannot be identified as a new species. These samples will be marked for a complex and complete taxonomic analysis. Therefore, defining this marker too quickly for atypical samples will have great potential for the discovery of fast species. I have it run as [44] DNA in the road as a standard barcode using the short gene, Provide fast, accurate and automatic type identification. It is a promising new system. Then, this result Environmentalists, ecologist, and institutions benefit greatly in the fight against pests, invasive species, and food security. More specifically, Linneo Easy-to-use classification system will be. Besides, with these popular skills and talents, DNA Bar codes accelerate the rate of species discovery, and short-term taxonomists focus on different groups that can represent new species. to be able to classify Due to the consideration of all potential benefits, no agreement has been reached. But part of the scientific community. In places, Practitioners and taxonomists have great debates. the [45]. Although some of these researchers will DNA the bar code is defined as an anti-taxonomy, but its practice has spent more than a quarter of a century in the field of taxonomy, this old the death of the system. Keep telling yourself. Ironically, funding has important and immediate drawbacks, but to date, DNA Barcodes the results could not be obtained. Visions centrifuge rich galvanization product and brought economic benefits. This finally affects the completion process, In the form of a complete and easily accessible system and as a modern tool of identification of species eternal inheritance way to do will [37]. They are more confirmed DNA code - bars Theme and destination It is defended by future scientists and is particularly effective in the identification and classification of new species in the animal world simply and profitably [46].

Take the 2005 relationships by DNA Identify a unique, simple, profitable and affordable way to solve a classification crisis [47]. Animal coding cytochrome c oxidase $1 \mathrm{~A}$ small fragment of the mitochondrial gene. In addition, in some cases, based on DNA the identification technique is very useful for the identification of children. If these associations are not known, associate gender or at least a different phase of life, small hat and we develop possible has been DNA barcodes this "DNA Classification" sample version. The results show that the use of short fragments of the mitochondrial gene can identify almost all members of the natural phase of the spider, take the despite DNA Bar codes represent great enthusiasm and criticism. but 2005 Repeat that you have more call. Misunderstanding content information [48]. But always say harm Why Classification in the definition, definition, identification, interpretation, and classification of species, [37] approves taxonomists you cannot use DNA to establish the bar code protocol and taxonomic diversity. However, this is due to the failure of the simulated gradient dimension, which results in the definition of the species in the usual way. The figure represents significant color changes. However, the scientific community waiting using DNA Digital structure of the painting allow the development of automated identification systems for known species, regardless of their type of life or gender. Finally, facilitating the identification of democratization and the acquisition of bar codes will help resolve the barriers to classification [36]. Besides, some people understand the tremendous benefits of different bar codes on organic bar codes. Instead of eliminating some gaps in the design of the experiments, we are in the middle of measuring to study this approach.

DNA Discovery and use of bar codes, Taxonomy of activation. They especially DNA barcode their use Talk about many critics Use as a competitor and send Already shown, in the reason for offered Traditional Taxonomy and DNA Synthesis of bar code classification combine, already done too much discussion, including DNA and morphology. The new technologies will be an excellent technical solution to fill this gap or they will complete this approach that many scientists can address and face in this controversial debate. DNA one thinks that the bar codes mobilize the traditional taxonomy, that the crisis of the classification overcomes the sphere of influence, adopts complementary methods and there are no alternative methods, but it supports the molecular taxonomy [49] besides increasing the use of computer tools and network. [38] Report says synthesis of spider fauna DNA There are few potential types identified in the reference library. The contrast causes the propagation of unlisted species. They, DNA Bar codes reliably identify spider species, DNA will Ability to conclude to allow the identification of bar codes, 
taxonomic samples (minors, women). Therefore, this represents a significant step forward in the future surveillance of spiders. In this research proposal, we will produce reference data for the leading local spiders and evaluate cytochrome c oxidase 1 effect new spider. Determination of population level. The senator another goal western Saudi Arabia These terrestrial and warm wadi ecosystems and agriculture Learn more about the key elements of biodiversity in ecosystems.

\section{The same permanent molecule.}

In the forest the city of southern Brazil and the habit of mosquitos' molecular identification of the blood of the Dipteral. The mosquito uses the energy obtained from the blood, which is the most feminine type of mosquito [50, 51] mainly, digestion and the production of eggs. Used with the participation of hemophilia in the efficiency of reproduction [52]. Foods, blood worms, various hosts such as blood leeches can include taxa [53], fish [54], amphibians, reptiles, birds, mammals, and so on. [55] Type-specific host preferences are inborn characteristics based on genetics but are governed by factors that affect the search patterns and host selection, such as environmental conditions and host characteristics. host [56]. Contact with different hosts allows the use of new vertebrate species for the transmission of pathogens [57]. The use of less diverse hosts allows some pathogens to contact and adopt specific hosts [58,59]. At the same time, opportunistic aerobic movements can cause pathogens to adapt and adapt to different vertebrate species [60, 61]. Understand mosquito reception patterns, understand their life cycle, survival, and reproduction. It helps to understand the effects of mosquito selection on the transmission of mosquito-borne pathogens. [62-65] Besides, this information is important for entomological studies. Provide information that will help in track monitoring [66], particularly under conditions of noise in the environment [67] to determine HIV blood and the power of molecular marker. Several methods were used as molecular methods. Identification, PCR based as a potential host only vertebrate, while a base assay illustrates the common precipitation tests and blood tests ELISA tests enzyme-linked immunosorbent assay This assay titration [68 -70]. Currently, determine the level of the species, using a molecular approach to perform the absorption of the DNA of blood $[71,72]$. The polymerase chain reaction (PCR) is then the simplest DNA sequence of the PCR product. It is an ideal option to study arthropods and is often used for wildlife [73]. Molecular methods should maximize the integrity of DNA molecules to optimally detect and amplify the target fragments [73]. The arthropods of the diet include the major degradation of DNA from the sample in the DNA laboratory. Collected digestion and extraction process /or caused by storage conditions [74]. Therefore, the degree of PCR in blood digestion defines the amplification and recognition of vertebrate hosts [75, 76]. Similarly, mosquitoes can approve unsaved temperatures and blood collection times, which may reduce the risk of identification [73, 77]. Since mosquitoes collected in the field have different degrees of digestion during the blood meal, it is important to evaluate the ideal storage conditions of mosquito dust in blood after harvest. Besides, it is necessary to determine the temperature limits and the storage duration of the mosquitoes used in the study, while trying to determine the selection of the host, but the ideal method is to store the DNA of the blood in the conditions of repopulation. $-80^{\circ} \mathrm{C}$ [77].

\section{CONCLUSIONS}

DNA barcodes have evolved significantly over the last decade in analytical procedures, data analysis, and applications to various biodiversity sciences. Classification is no exception. In addition to linking the DNA world with traditional taxonomy based on morphological features, DNA barcodes have set new standards for data quality, accessibility, and reproducibility. Use of DNA Sequences in other areas of biology are more durable. After about 10 years, DNA barcodes introduce an automatic, fast and objective method for detecting biodiversity based on DNA sequences, an unprecedented opportunity for a global inventory of organisms on earth We have opened universe. DNA barcodes also challenge taxonomy and describe morphological features and often to its old custom in producing essential species that are unrelated to prosperous regional communities to challenge in species such as ecosystems. The use of tropical DNA sequences not only provides an objective method for species delineation and new species identification tools but more importantly, challenges the way we collect, maintain and publish species. The Knowledge of the species paving the way for more sustainable practices in biodiversity and taxonomy.

\section{CONFLICT OF INTEREST}

The authors declare no conflicts of interest.

\section{ACKNOWLEDGMENT}

The author support from the Dept. of Biological Sciences, Faculty of Science, King Abdulaziz University (KAU), Jeddah, KSA. The author would like to thank for prof Mohamed Morsi M. Ahmed for his help in this article.

\section{REFERENCES}

1. Camila Silva Santos, Marcio Roberto Pie, Tatiana Carneiro da Rocha, Mario Antonio Navarro-Silva 2019. Molecular identification of blood meals in mosquitoes (Diptera, Culicidae) in urban and forested habitats in southern Brazil, Polse one $1-18$.

2. Nicolas Hubert, Robert Hanner DNA Barcoding, species delineation and taxonomy: a historical perspective, DNA Barcodes 2015; Volume 3: 44-58.

3. Al-Ghamdi, K.M.S. and A.A. Faragalla. 1999. Occurrence of jumping spiders (Araneae: Salticidae) in Alfalfa agroecosystems in Saudi Arabia. Arab Gulf Journal of Scientific Research. 254-245:(2)17. 
Citation: Naser Alkenani and Habeeb M. Al-Solami, 2019. Molecular identification of Insect species and their applications. Advances in Environmental Biology 13(8): 17-24. DOI:10.22587/aeb.2019.13.8.2

4. Faragalla, A.A. and Al Ghamdi, K.M.S. 2001. Comparison of the seasonal occurrence of the major true spiders (Araneidae) in some crop systems and a natural habitat, in Western Saudi Arabia. Arch. Phytopath. Pflanz. Vol. 377-361, 34.

5. Jacob M (2001) Scientists target return of infectious diseases. Gen Eng News 21(10):11-80.

6. Lam SK (1993) Rapid dengue diagnosis and interpretation. Malays J Pathol 15:9-12.

7. Gubler DJ (2002) The global emergence/resurgence of arboviral diseases as public health problems. Arch Med Res 33(4):330-342.

8. WHO, Geneva, Switzerland WHO (1999) Prevention and Control of Dengue and Dengue Haemorrhagic Fever: Scientific working group on dengue, Meeting report, Geneva, Switzerland, 3-5 April 2000. Geneva: WHO, 2000.

9. WHO (2000) Guidelines for Surveillance and Mosquito Control, Sec. ed. WHO Regional Office Edu. In Action Series 8-12 Wilder-Smith A, Schwartz E (2005) Dengue in travellers. NEJM 353 (9):924-932.

10. Zaki A, Perera D, Jahan SS, Cardosa MJ (2008) Phylogeny of dengue viruses circulating in Jeddah, Saudi Arabia: 1994 to 2006. Trop Med Int Health 13(4):584-592.

11. Khan NA, Azhar EI, El-Fiky S, Madani HH, Abuljadial MA, Ashshi AM, Turkistani AM, Hamouh EA (2008) Clinical profile and outcome of hospitalized patients during first outbreak of dengue in Makkah, Saudi Arabia. Acta Trop 105(1):3944. doi:10.1016/ j.actatropica. 2007.09.005.

12. Ito M, Takasaki T, Yamada K, Nerome R, Tajima S, Kurane I (2004) Development and evaluation of fluorogenic Taq Man reverse transcriptase PCR assays for detection of dengue virus types 1 to 4. J ClinMicrobiol 42(12):5935-5937.

13. Putonti C, Chumakov S, Mitra R, Fox GE, Willson RC, Fofanov Y (2006) Human-blind probes and primers for dengue virus identification Exhaustive analysis of subsequences present in the human and 83 dengue genome sequences. FEBS J 273:398408.

14. Guzman MG, Kouri G (2004) Dengue diagnosis, advances and challenges. Int J Infect Dis 8(2):69-80

15. Innis BL, Nisalak A, Nimmannitya S, Kusalerdchariya S, Chongswadi V, Suntayakorn S, Puttisri P, Hoke CH (1989) An enzyme linked immunosorbent assay to characterize dengue infections where dengue and Japanese encephalitis co-circulate. AmJTrop Med Hyg 40:418-427.

16. Vorndam V, Kuno G (1997) Laboratory diagnosis of dengue virus infections. In: Gubler DJ, Kuno G (eds) Dengue and dengue hemorrhagic fever. CAB International, New York, N.Y., pp 313-334.

17. Guzman MG, Kouri G (1996) Advances in dengue diagnosis. Clin Diagn Lab Immunol 3:621-627.

18. Harris E, Roberts TG, Smith L, Selle J, Kramer LD, Valle S, Sandoval E, Balmaseda A (1998) Typing of dengue viruses in clinical specimens and mosquitoes by single-tube multiplex reverse transcriptase PCR. J Clin Microbiol 36:2634-2639.

19. Kuno G (1998) Universal diagnostic RT-PCR protocol for arboviruses. J Virol Methods 72:27-41.

20. WHO (1997) Dengue haemorrhagic fever: Diagnosis, treatment, prevention and control, 2nd edn.

21. Gubler DJ (1998) Dengue and dengue hemorrhagic fever. Clin Microbiol Rev 11(3):480-496.

22. Harbach, R.E., Howard, T.M., 2007, Index of currently recognized mosquito species (Diptera: Culicidae). Eur. Mosq. Bull 23, 1-66.19.

23. Lundstrom, J.O., Andersson, A.C., Backman, S., Schafer, M.L., Forsman, M., Thelaus, J., 2011, Transstad ial Transmission of Francisella tularensis holarctica in Mosquitoes, Sweden. Emerging Infect. Dis. 17, 794-799.

24. Gerhardt, K., Iwarsson, M., Tunón, H., CBM 2013. Sammanställning och bedömning av myggbegränsningsmetoder i Sverige och andra länder. (Gävle, County Administrative Board Gävleborg). Hall, T.A., 1999, BioEdit: a user-friendly biological sequence alignment editor and analysis program for Windows 95/98/NT. Nucleic Acids Symp. Ser. 41, 95-98.

25. Erik Helmersson, 2013 Molecular identification of mosquito species Evaluation of a rapid DNA extraction method together with DNA barcoding as a tool for identification of species, Bachelor of science, 1-23.

26. Hebert, P.D.N., Cywinska, A., Ball, S.L., and deWaard, J.R. 2003a. Biological identifications through DNA barcodes. Proc. R. Soc. Lond. B Biol. Sci. 270: 313-321.

27. Adl, S.M., Leander, B.S., Simpson, A.G., Archibald, J.M., Anderson, O.R., Bass, D., Bowser, S.S., Brugerolle, G., Farmer, M.A., Karpov, S., 2007, Diversity, nomenclature, and taxonomy of protists. Syst. Biol. 56, 684-689.

28. Arif, I.A., Bakir, M.A., Khan, H.A., Al Farhan, A.H., Al Homaidan, A.A., Bahkali, A.H., Al Sadoon, M., Shobrak, M., 2010, A brief review of molecular techniques to assess plant diversity. Int. J. Mol. Sci. 11, 2079-2096.

29. Doyle, J.J., Gaut, B.S., 2000, Evolution of genes and taxa: a primer. Plant Mol. Biol. 42, 1-23.

30. Chen, S., Yao, H., Han, J., Liu, C., Song, J., Shi, L., Zhu, Y., Ma, X., Gao, T., Pang, X., 2010, Validation of the ITS2 region as a novel DNA barcode for identifying medicinal plant species. PloS One 5, e8613.

31. Hebert, P.D.N., Ratnasingham, S. \& deWaard, J.R. 2003b. Barcoding animal life;cytochrome c oxidase subunit 1 divergenses among closely related speices. Proc. R. Soc. Lond. B. Biol. Sci. 270 (Suppl.): S96-S99.

32. Folmer, O., Black, M., Hoeh, W., Lutz, R., Vrijenhoek, R., 1994, DNA primers for amplification of mitochondrial cytochrome c oxidase subunit I from diverse metazoan invertebrates. Mol. Mar. Biol. Biotech, 3, 294-299.

33. Stoeckle, M., 2003, Taxonomy, DNA, and the bar code of life. Bioscience 53, 796-797.

34. Stoeckle, M., Janzen, D., Hallwachs, W., Hanken, J., Baker, J. 2003. Taxonomy, DNA and the barcode of life. (New York, NY, Banbury Center, Cold Spring Harbor Laboratory). SVA 2013. Lyckad myggjakt 2012. WWW-document 2013-01-18:

35. Ratnasingham, S., Hebert, P.D., 2007, bold: The Barcode of Life Data System (http://www.barcodinglife.org). Mol. Ecol. Notes 7, 355-364. 20.

36. Janzen, D.H. 2004. Now is the time. Philos. Trans. R. Soc. Lond. B. Biol. Sci.No. 359, pp.731-732.

37. Barrett, R.D.H., and Hebert, P.D.N. 2005. Identifying spiders through DNA barcodes. Can. J. Zool. 83(3): $481-491$.

38. Blagoev, G. A., Nikolova, N.I., Sobel, C.N., Hebert, P.D.N. and Adamowicz, S.J. 2013. Spiders (Araneae) of Churchill, Manitoba: DNA barcodes and morphology reveal high species diversity and new Canadian records. BMC Ecology. 
39. Hebert, P. D. N., 2014. Bar code of Life.

40. Hajibabaei, M, Singer, G.A.C., Hebert, P.D.N. \& Hickey, D. A. 2007. DNA barcoding: how it complements taxonomy, molecular phylogenetic and population genetics. Trends. Genet.23:167-172.

41. Cameron, S., Rubinof F, D., Will, K. 2006. Who will actually use DNA Barcoding and what will it cost. Syst.Biol.55:844847.

42. Hebert PDN, Cywinska A, Ball SL, de Waard JR. 2003 Biological identifcations through DNA barcodes. Proc Biol Sci.; 270:313-21.

43. Hajibabaei, M., Smith, M.A., Janzen, D.H., Rodriguez, J.J., Whitfiels, J.B., \& Hebert, P.D.N.2006b a minimalist barcode can identity a specimen whose DNA is degraded. Mol. Ecol. Notes.6:959-964

44. Hebert, P.D.N. and Gregory, T.R. 2005. The Promise of DNA Bar Coding for Taxonomy. Syst. Biol. 54 (5) 852859.

45. Will, K.W., B.D. Mischler, and Q.D. Wheeler. 2005. The perils of DNA barcoding and the need for integrative taxonomy. Syst. Biol. 54:844-851.

46. Padial, J.M, \& Delariva, I. 2007 Integrative taxonomist should use and produce DNA barcodes. Zootaxa 1586:67-68.

47. Robinson, E.A., Blagoev, G.A., Hebert, P.D.N., Adamowcitz, S.J. 2009. Prospects for using DNA bar coding to identify spiders in species-rich genera. ZooKeys 16:27-46.

48. Will, K.W., and D. Rubinoff. 2004. Myth of the molecule: DNA barcodes for species cannot replace morphology for identification and classification. Cladistics 20:47-55.

49. Tautz, D., Arctander, P. Minelli, A. Thomas, R.H. \& Vogler,A.P. 2003. A plea for DNA taxonomy. Trend Ecol. Evol.18:7074.

50. Camila Silva Santos, Marcio Roberto Pie, Tatiana Carneiro da Rocha, Mario Antonio Navarro-Silva 2019. Molecular identification of blood meals in mosquitoes (Diptera, Culicidae) in urban and forested habitats in southern Brazil, Polse one $1-18$.

51. Harbach RE. The Culicidae (Diptera): A review of taxonomy, classification and phylogeny. Zootaxa. 2007 ; $1668: 591-638$.

52. Phasomkusolsil S, Pantuwattana K, Tawong J, Khongtak W, Kertmanee Y, Monkanna N, et al. The relationship between wing length, blood meal volume, and fecundity for seven colonies of Anopheles species housed at the Armed Forces Research Institute of Medical Sciences, Bangkok, Thailand. Acta Trop. 2015; 152: 220-227.

53. Reeves LE, Holderman CJ, Blosser EM, Gillett-Kaufman JL, Kawahara AY, Kaufman PE, et al. Identification of Uranotaenia sapphirina as a specialist of annelids broadens known mosquito host use patterns. Commun Biol. 2018; 1: 92.

54. Toma T, Miyagi I, Tamashiro M. Blood meal identification and feeding habits of Uranotaenia species collected in the Ryukyu Archipelago. J Am Mosq Control Assoc. 2014; 30: 215-218.

55. Forattini OP, Gomes AC, Natal D, Kakitani I, Marucci D. Preferências alimentares de mosquitos Culicidae no Vale do Ribeira, São Paulo, Brasil. Rev Saude Publica. 1987; 21: 171-187.

56. Takken W, Verhulst NO. Host preferences of blood-feeding mosquitoes. Annu Rev Entomol. 2013; 58:433-453.

57. Kilpatrick AM, Daszak P, Jones MJ, Marra PP, Kramer LD. Host heterogeneity dominates West Nile Virus transmission. Proc R Soc B Biol Sci. 2006; 273: 2327-2333.

58. Kenney JL, Brault AC. The role of environmental, virological and vector interactions in dictating biological transmission of arthropod-borne viruses by mosquitoes. Adv Virus Res. 2014; 89: 39-83.

59. Musso D, Gubler DJ. Zika virus. Clin Microbiol Rev. 2016; 29: 487-524.

60. Hamer GL, Kitron UD, Goldberg TL, Brawn JD, Loss SR, Ruiz MO, et al. Host selection by Culex pipiens mosquitoes and West Nile Virus amplification. Am J Trop Med Hyg. 2009; 80: 268-278.

61. Sotomayor-Bonilla J, Abella-Medrano CA, Chaves A, A’ lvarez-Mendiza bal P, Rico-Cha'vez O’, Iba'ñezBernal S, et al. Potential sympatric vectors and mammalian hosts of Venezuelan Equine EncephalitisVirus in Southern Mexico. J Wildl Dis. 2017; 53: 657-661.

62. Styer LM, Minnick SL, Sun AK, Scott TW. Mortality and reproductive dynamics of Aedes aegypti (Diptera: Culicidae) fed human blood. Vector Borne Zoonotic Dis. 2007; 7: 86-98.

63. Kent RJ. Molecular methods for arthropod bloodmeal identification and applications to ecological and vector-borne disease studies. Mol Ecol Resour. 2009; 9: 4-18.

64. Lyimo IN, Keegan SP, Ranford-Cartwright LC, Ferguson HM. The impact of uniform and mixed species blood meals on the fitness of the mosquito vector Anopheles gambiae s.s: Does a specialist pay for diversifying its host species diet? J Evol Biol. 2012; 25: 452-460.

65. Faraji A, Egizi A, Fonseca DM, Unlu I, Crepeau T, Healy SP, et al. Comparative host feeding patterns of the Asian Tiger Mosquito, Aedes albopictus, in urban and suburban Northeastern USA and implications for disease transmission. PLoS Negl Trop Dis. 2014; 8: e3037.

66. Regis L, Souza W V, Furtado AF, Fonseca CD, Silveira JC, Ribeiro PJ, et al. An entomological surveillance system based on open spatial information for participative dengue control. An Acad Bras Cienc. 2009; 81: 655-662.

67. Reiter P. Climate change and mosquito-borne disease. Environ Health Perspect. 2001; 109: 141-161.

68. Gomes LAM, Duarte R, Lima DC, Diniz BS, Serrão ML, Labarthe N. Comparison between precipitin and ELISA tests in the bloodmeal detection of Aedes aegypti (Linnaeus) and Aedes fluviatilis (Lutz) mosquitoes experimentally fed on feline, canine and human hosts. Mem Inst Oswaldo Cruz. 2001; 96: 693-695.

69. Alencar J, Mello CF, Gil-Santana HR, Giupponi APL, Arau'jo AN, Lorosa ES, et al. Feeding patterns of mosquitoes (Diptera: Culicidae) in the Atlantic Forest, Rio de Janeiro, Brazil. J Med Entomol. 2015; 52: 783-788. 
70. Mucci LF, Cardoso Júnior RP, Paula MB, Scandar SAS, Pacchioni ML, Fernandes A, et al. Feeding habits of mosquitoes (Diptera: Culicidae) in an area of sylvatic transmission of yellow fever in the state of São Paulo, Brazil. J Venom Anim Toxins Incl Trop Dis. 2015; 21: 6.

71. Kirchgatter K, Tubaki RM, Malafronte RS, Alves IC, Lima GFMC, Guimarães LO, et al. Anopheles (Kerteszia) cruzii (Diptera: Culicidae) in peridomiciliary area during asymptomatic malaria transmission in the Atlantic Forest: molecular identification of blood-meal sources indicates humans as primary intermediate hosts. Rev Inst Med Trop Sao Paulo. 2014; 56: 403-409.

72. Hernandez-Triana LM, Brugman VA, Prosser SWJ, Weland C, Nikolova N, Thorne L, et al. Molecular approaches for blood meal analysis and species identification of mosquitoes (Insecta: Diptera: Culicidae) in rural locations in southern England, United Kingdom. Zootaxa. 2017; 4250: 67-76.

73. Mukabana WR, Takken W, Knols BGJ. Analysis of arthropod bloodmeals using molecular genetic markers. Trends Parasitol. 2002; 18: 505-509.

74. Oshaghi MA, Chavshin AR, Vatandoost H, Yaaghoobi F, Mohtarami F, Noorjah N. Effects of post-ingestion and physical conditions on PCR amplification of host blood meal DNA in mosquitoes. Exp Parasitol. 2006; 112: 232-236.

75. Ngo KA, Kramer LD. Identification of mosquito bloodmeals using Polymerase Chain Reaction (PCR) with order-specific primers. J Med Entomol. 2003; 40: 215-222.

76. Mukabana WR, Takken W, Seda P, Killeen GF, Hawley WA, Knols BGJ. Extent of digestion affects the success of amplifying human DNA from blood meals of Anopheles gambiae (Diptera: Culicidae). Bull Entomol Res. 2002; 92: 233239.

77. Reeves LE, Holderman CJ, Gillett-Kaufman JL, Kawahara AY, Kaufman PE. Maintenance of host DNA integrity in fieldpreserved mosquito (Diptera: Culicidae) blood meals for identification by DNA barcoding. Parasites \& Vectors.2016; 9: 503. 